Resectron

\title{
Cellular insulin resistance disrupts hypothalamic mHypoA-POMC/GFP neuronal signaling pathways
}

\author{
Anaies Nazarians-Armavil', Jennifer A Chalmers ${ }^{1}$, Claire B Lee', Wenqing $\mathrm{Ye}^{1}$ and \\ Denise D Belsham ${ }^{1,2,3,4}$
}

Departments of ${ }^{1}$ Physiology, ${ }^{2}$ Obstetrics and Gynaecology and ${ }^{3}$ Medicine, University of Toronto, Medical Sciences Building 3344, 1 Kings College Circle, Toronto, Ontario, Canada M5S 1A8

${ }^{4}$ Division of Cellular and Molecular Biology, Toronto Genera Hospital Research Institute, University Health Network, Toronto, Ontario, Canada M5S 1A8
Correspondence should be addressed to D D Belsham

Email

d.belsham@utoronto.ca

\begin{abstract}
POMC neurons play a central role in the maintenance of whole-body energy homeostasis. This balance requires proper regulation of POMC neurons by metabolic hormones, such as insulin. However, the heterogeneous cellular population of the intact hypothalamus presents challenges for examining the molecular mechanisms underlying the potent anorexigenic effects of POMC neurons, and there is currently a complete lack of mature POMC neuronal cell models for study. To this end, we have generated novel, immortalized, adult-derived POMC-expressing/ $\alpha$-MSH-secreting cell models, mHypoA-POMC/GFP lines 1-4, representing the fluorescence-activated cell-sorted POMC population from primary POMCeGFP mouse hypothalamus. The presence of Pomc mRNA in these cell lines was confirmed, and $\alpha$-MSH was detected via immunofluorescence. $\alpha$-MSH secretion in the mHypo-

POMC/GFP-1 was found to increase in response to $10 \mathrm{ng} / \mathrm{ml}$ ciliary neurotrophic factor (CNTF) or $10 \mathrm{nM}$ insulin as determined by enzyme immunoassay. Further experiments using the mHypoA-POMC/GFP- 1 cell line revealed that $10 \mathrm{ng} / \mathrm{ml}$ CNTF increases Pomc mRNA at 1 and $2 \mathrm{~h}$ after treatment, whereas insulin elicited an increase in Pomc mRNA level and decreases in insulin receptor (Insr (Ir)) mRNA level at $4 \mathrm{~h}$. Furthermore, the activation of IR-mediated downstream second messengers was examined by western blot analysis, following the induction of cellular insulin resistance, which resulted in a loss of insulin-mediated regulation of Pomc and Ir mRNAs. The development of these immortalized neurons will be invaluable for the elucidation of the cellular and molecular mechanisms that underlie POMC neuronal function under normal and perturbed physiological conditions.
\end{abstract}

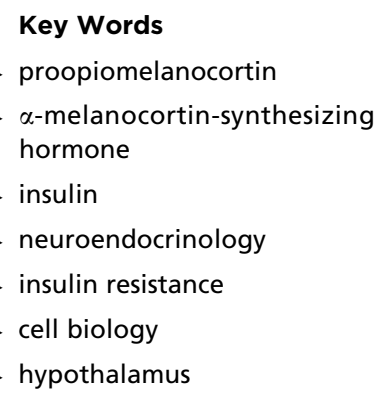

\section{Introduction}

The hypothalamus is largely responsible for the integration of peripheral cues, such as hormones and nutrients, to direct appropriate physiological processes to maintain energy balance. Disruption in this equilibrium results in the central development of obesity and type 2 diabetes (T2DM) through the impaired function of the arcuate nucleus (ARC) of the hypothalamus (Mountjoy \& Wong 1997, Arora \& Anubhuti 2006, Morton et al. 2006). The ARC is critical to the control of metabolism as it contains two essential neuronal subpopulations, the 
anorexigenic proopiomelanocortin (POMC) neurons and orexigenic neuropeptide $\mathrm{Y} /$ agouti-related peptide (NPY/AgRP) neurons, which form the basis of the primary feeding circuits that regulate appetite and body weight (Cone et al. 2001). Activation of NPY/AgRP neurons promotes an increase in food intake and energy storage while activation of POMC neurons results in feeding suppression and energy expenditure.

Peripheral satiety signals, such as insulin, gain access to the ARC of the hypothalamus and regulate POMC neurons (Baskin et al. 1999). Insulin signal transduction has been defined in the periphery and in the whole hypothalamus. Upon insulin binding, the insulin receptor (IR) dimerizes and is transphosphorylated at specific tyrosine residues, recruiting and phosphorylating IR substrate (IRS). Phosphorylated IRS activates phosphoinositide 3-kinase (PI3K) ultimately leading to phosphorylation of Akt, which triggers several downstream signaling cascades, including the inhibitory phosphorylation of the transcription factor forkhead box protein O1 (FOXO1). Activated FOXO1 induces Npy transcription and represses Pomc expression, while inhibitory phosphorylation of FOXO1 causes its translocation out of the nucleus, resulting in increased Pomc mRNA and decreased Npy mRNA levels (Kim et al. 2006, Kitamura et al. 2006, Plum et al. 2006a). Insulin signal transduction also stimulates the MAPK pathway leading to mitogenesis (Reusch et al. 1995).

Despite our growing understanding of insulin signal transduction, much remains to be elucidated regarding the effects of insulin specific to neuronal subpopulations of the hypothalamus. The modulation of POMC neurons by signals from the periphery and the CNS, including insulin, leptin, serotonin, ciliary neurotrophic factor (CNTF), glucose, and fatty acids, merits further investigation (Xu et al. 2008, 2010, Couvreur et al. 2011). Additionally, emerging in the literature are numerous processes that contribute to the pathophysiology of the metabolic syndrome, including hormone resistance, inflammation, and autophagy (Kaushik et al. 2012, Varela \& Horvath 2012). In particular, obesity is frequently associated with central insulin resistance, or the inability of insulin to exert its appropriate effects on key hypothalamic neuronal populations (Konner \& Bruning 2012). It is now becoming accepted that hormone resistance does not affect all neurons uniformly but can perturb specific downstream pathways within a cell or affect specific neuronal subpopulations (Konner \& Bruning 2012). All this warrants more research into the functional differences between diverse neuronal subpopulations.
The Cre-lox technology has led to substantial advancements in our understanding of the regulators of POMC neuronal function. For example, in mice lacking IRs and leptin receptors specifically in POMC neurons (Pomc-Cre, Lepr flox/flox , and $I r^{\text {flox/flox }}$ mice), it has been confirmed that the direct action of these hormones on POMC neurons is essential for the maintenance of energy and glucose homeostasis (Hill et al. 2010). However, mechanistic studies are vital to increasing our understanding of the disturbances in molecular processes that underlie the development of obesity, T2DM, and other diseases associated with the metabolic syndrome. But it remains challenging to perform detailed molecular studies on the transcriptional regulation of neuropeptides, signal transduction events, and especially secretion of bioactive molecules occurring within POMC neurons, due to the anatomical complexity of the hypothalamus compounded by the complete lack of mature POMC neuronal cell models. Hence, the immortalization of mature POMC neurons would be favorable to facilitate the investigation of the cellular and molecular mechanisms underlying their physiology and pathophysiology. To this end, our laboratory has generated four cell models representing the entire complement of hypothalamic POMC neurons from adult POMC-eGFP transgenic mice. Herein, we present the characterization of the neuronal cell models mHypoAPOMC/GFP lines 1-4 under insulin-sensitive and insulinresistant states, with the dual purpose of contributing to our understanding of the metabolic syndrome while providing researchers with representative in vitro models of POMC neurons.

\section{Materials and methods}

\section{mHypoA-POMC/GFP cell line immortalization and flow cytometry}

Adult mouse hypothalamic neurons were immortalized as described previously (Belsham et al. 2009). In brief, four males, 8-week-old mice containing an eGFP transgene driven by the POMC promoter (strain C57BL/6J-Tg(PomcEGFP)1Low/J) were obtained from The Jackson Laboratory (Bar Harbor, ME, USA) and individual hypothalamii were isolated and dispersed into primary culture. All animal procedures were approved and performed in accordance with the Animal Use Protocols at the University of Toronto. Each culture was treated with $10 \mathrm{ng} / \mathrm{ml}$ CNTF (in PBS, R\&D Systems, Minneapolis, MN, USA) to induce neuronal proliferation, allowing for viral infection with a plasmid construct containing the oncogene SV40

Published by Bioscientifica Ltd 
T-antigen and a neomycin resistance cassette. Cells that successfully incorporated the construct were selected for by treatment with $100 \mu \mathrm{g} / \mathrm{ml}$ G418 (Geneticin; Gibco, Life Technologies), a neomycin analog. Following immortalization, in order to select for POMC neurons specifically, each hypothalamic culture was fluorescence-activated cell (FAC)-sorted to separate GFP-expressing cells from nonfluorescent cells using a protocol previously described (Dhillon et al. 2011). Four cell lines representing the heterogeneous population of hypothalamic POMC neurons were generated: mHypoA-POMC/GFP lines 1-4, which were used for further characterization. We also isolated one line from the pituitary of mouse 1 (mPitAPOMC/GFP-1) and found by immunocytochemistry (ICC) that it expressed adrenocorticotropic hormone (ACTH) peptide, a tissue-specific processing product from the Pomc gene in the pituitary. This line is not yet characterized.

\section{Cell culture and reagents}

mHypoA-POMC/GFP neurons were grown in DMEM (Sigma-Aldrich) supplemented with $5 \%$ fetal bovine serum (FBS), 1000 or $4500 \mathrm{mg} / \mathrm{l}$ glucose (low glucose and high glucose respectively), and $1 \%$ penicillin-streptomycin (Gibco, Life Technologies). Cells were cultured in 5\% $\mathrm{CO}_{2}$ at $37^{\circ} \mathrm{C}$. Passage number is consistently limited to under 25. Human biosynthetic insulin gifted by Novo-Nordisk Canada, Inc. (Mississauga, ON, Canada) and CNTF were diluted in PBS prior to use in experiments.

\section{Semiquantitative RT-PCR}

mHypoA-POMC/GFP neurons were grown in $60 \mathrm{~mm}$ plates (Sarstedt, Montreal, QC, Canada) to $\sim 80-85 \%$ confluency using high-glucose DMEM supplemented with 5\% FBS. Total RNA was extracted from the mHypoA-POMC/GFP cells via the guanidinium thiocyanate phenol chloroform extraction method (Chomczynski \& Sacchi 1987, Belsham et al. 2004). The RNA samples were quantified using the NanoDrop 2000c spectrophotometer (Thermo Fisher Scientific, Waltham, MA, USA). RNA was treated with Turbo DNase (Ambion, Life Technologies) to remove genomic DNA in the samples prior to performing one-step RT-PCR using the SuperScript III One-Step RT-PCR System with Plantinum Taq DNA Polymerase (Life Technologies). One-step RT-PCR was performed using 200-400 ng DNase-treated RNA template combined with OneStep RT-PCR buffer, dNTPs, enzyme mix, and primers according to manufacturer's instructions. PCR products were analyzed via agarose gel electrophoresis. PCR samples were resolved on a $2 \%$ agarose gel containing ethidium bromide and visualized under u.v. light using the Kodak Image Station 2000R. PCR products were sequenced by The Centre for Applied Genomics (TCAG, Toronto, ON, Canada) to confirm fragment identity. Primer sequences are listed in Supplementary Table 1 , see section on supplementary data given at the end of this article.

Immunocytochemistry All cell lines were cultured for ICC on eight-well slides (BD Falcon, Mississauga, ON, Canada) at $37^{\circ} \mathrm{C}$ with $5 \% \mathrm{CO}_{2}$. Cells were grown to $75-80 \%$ confluency in using high-glucose DMEM supplemented with 5\% FBS and processed using methods described previously (Dhillon et al. 2011). Briefly, the cells were washed with PBS and fixed using 4\% paraformaldehyde in PBS (Electron Microscopy Sciences, Hatfield, PA, USA). Cells were then washed again with PBS and then permeated with $0.2 \%$ Triton X-100 (in PBS) (SigmaAldrich). Cells were blocked with 5\% BSA (Sigma-Aldrich) and $0.1 \%$ Triton X-100 in PBS overnight at $4{ }^{\circ} \mathrm{C}$. Primary antibody incubation was conducted for $2 \mathrm{~h}$ at room temperature. Primary antibodies to $\alpha$-melanocytestimulating hormone ( $\alpha$-MSH) and GFP (Abcam, Inc., Cambridge, MA, USA) were diluted 1:200 in antibody dilution buffer (1\% BSA and 0.1\% Triton X-100 in PBS). Control wells were also incubated with $1 \%$ BSA and $0.1 \%$ Triton X-100 in PBS. Cells were then incubated with Alexa Fluor 555 goat anti-rabbit and Alexa Fluor 488 donkey anti-mouse secondary antibodies diluted $1: 500$ in antibody dilution buffer, with the addition of TO-PRO-3 nuclear stain (1:1000 dilution) for $1 \mathrm{~h}$ (Life Technologies). Gaskets were mounted with ProLong Gold Antifade Reagent (Life Technologies). Cells were then visualized with a confocal laser-scanning microscope using an oil lens at a magnification of $40 \times$ (LSM 510; Carl Zeiss). GFP fluorescence was excited by the $488 \mathrm{~nm}$ argon laser line, and $\alpha-\mathrm{MSH}$ and TO-PRO-3 were excited by the $543 \mathrm{~nm}$ helium-neon and the $633 \mathrm{~nm}$ helium-neon laser line respectively.

Enzyme immunoassay mHypoA-POMC/GFP-1 cells were grown on 24-well tissue culture plates (BD Falcon) to $85-90 \%$ confluency at $37{ }^{\circ} \mathrm{C}$ with $5 \% \mathrm{CO}_{2}$. For the secretion assay, cells were incubated with $300 \mu \mathrm{l}$ of lowglucose DMEM (Sigma-Aldrich), containing 5\% FBS and $1 \%$ penicillin-streptomycin overnight $(\sim 16 \mathrm{~h})$. The following morning, the media were removed from the designated wells and replaced with the low-glucose DMEM containing one of the following: PBS, $10 \mathrm{ng} / \mathrm{ml} \mathrm{CNTF}$, or

Published by Bioscientifica Ltd. 
$10 \mathrm{nM}$ insulin, and incubated for $1 \mathrm{~h}$. At the 40-min time point in this incubation, media were removed from wells allocated for the positive control group and was replaced with media containing $60 \mathrm{mM} \mathrm{KCl}$. After a 20-min incubation, $250 \mu 1$ media from each well were collected, placed in borosilicate glass tubes (VWR, Mississauga, ON, Canada), and dried and then finally stored at $-80^{\circ} \mathrm{C}$ until processing. Cells were washed once with cold PBS and lysed using $1 \times$ lysis buffer (Cell Signaling Technology, Inc., Danvers, MA, USA) with $1 \mathrm{mM}$ PMSF (Sigma-Aldrich). Cells were scraped from the 24-well plates, vortexed briefly, and spun at 14000 r.p.m. for $10 \mathrm{~min}$, after which the supernatant was transferred to a fresh tube. Protein was quantified using a bicinchoninic acid (BCA) protein assay kit (Pierce, Thermo Fisher Scientific). Samples were collected in triplicate for each experimental repeat. $\alpha$-MSH secretion was determined via enzyme immunoassay (EIA; Phoenix Pharmaceuticals, Inc., Burlingame, CA, USA). For this assay, the dried samples were rehydrated in $50 \mu \mathrm{l} 1 \times$ assay buffer and the entirety of the sample was loaded onto the assay plate. $\alpha$-MSH secretion values were normalized to total protein values.

\section{Quantitative real-time RT-PCR (qRT-PCR)}

mHypoA-POMC/GFP-1 neurons were grown in $60 \mathrm{~mm}$ plates (Sarstedt) to $\sim 80-85 \%$ confluency using highglucose DMEM supplemented with 5\% FBS. For 8-h time course experiments, media were changed to low-glucose DMEM supplemented with 5\% FBS overnight prior to starting the time course. Treatments were $10 \mathrm{nM}$ insulin or $10 \mathrm{ng} / \mathrm{ml} \mathrm{CNTF}$ or PBS as a negative control. For insulin resistance experiments, mHypo-POMC/GFP-1 cells were pretreated for $24 \mathrm{~h}$ with $100 \mathrm{nM}$ insulin or PBS. To maintain elevated insulin levels, treatment or control media were refreshed $12 \mathrm{~h}$ after the start of pretreatment. Following pretreatment, the cells were washed with PBS and then re-challenged with $10 \mathrm{nM}$ insulin or PBS. Cells were harvested $4 \mathrm{~h}$ following re-challenge. RNA was isolated and treated with DNase as described earlier and then reverse transcribed using the High Capacity cDNA Reverse Transcription Kit (Applied Biosystems, Life Technologies). Next, 50 ng cDNA was amplified by real-time PCR using a premade master mix: Platinum SYBR Green qPCR SuperMix-UDG w/ROX (Life Technologies), with primers specific to each gene of interest. Each sample was run in triplicate on the Prism 7900HT Sequence Detection System (Applied Biosystems, Life Technologies) and amplified with the following conditions: $2 \mathrm{~min}$ at $50^{\circ} \mathrm{C}$,
2 min at $95^{\circ} \mathrm{C}, 40$ cycles of $15 \mathrm{~s}$ at $95^{\circ} \mathrm{C}$ followed by $1 \mathrm{~min}$ at $60^{\circ} \mathrm{C}, 15 \mathrm{~s}$ at $95^{\circ} \mathrm{C}, 15 \mathrm{~s}$ at $60^{\circ} \mathrm{C}$, and finally $15 \mathrm{~s}$ at $95^{\circ} \mathrm{C}$. qRT-PCR data were quantified using the standard curve method and normalized to the housekeeping gene, histone 3A. Primer sequences are listed in Supplementary Table 2, see section on supplementary data given at the end of this article.

\section{Western blot analysis}

For 1-h time course experiments, mHypoA-POMC/GFP cells were grown to $\sim 95 \%$ confluency, serum-starved for $4 \mathrm{~h}$, and then treated with $10 \mathrm{nM}$ insulin or PBS. For insulin resistance experiments, mHypoA-POMC/GFP cells were pretreated with $100 \mathrm{nM}$ insulin or PBS for $24 \mathrm{~h}$. Media were removed and replaced with fresh treatment media at the mid-point of the pretreatment period to maintain elevated insulin levels. Following $24 \mathrm{~h}$ of insulin pretreatment, the cells were washed with PBS and incubated for $1 \mathrm{~h}$ in fresh low-glucose DMEM (0\% FBS) without insulin to allow protein phosphorylation levels to return to basal levels. Next, the cells were re-challenged with $10 \mathrm{nM}$ insulin or PBS control for $15 \mathrm{~min}$ prior to protein harvesting.

Protein was harvested using a $1 \times$ lysis buffer (Cell Signaling Technology, Inc.) supplemented with $1 \mathrm{mM}$ PMSF, Phosphatase Inhibitor Cocktail 2 (Sigma-Aldrich), and Protease Inhibitor Cocktail (Sigma-Aldrich) according to manufacturer's instructions. Twenty-five micrograms of protein were run on an $8-10 \%$ SDS-polyacrylamide gel and transferred onto Immobilon-P PVDF membranes (BioRad). The membranes were blocked and incubated overnight with primary antibody at $4{ }^{\circ} \mathrm{C}$ and subsequently with HRP-linked secondary antibody for $1 \mathrm{~h}$. Blots were visualized by exposure to the Amersham ECL Select Western blotting detection reagent (GE Healthcare, Baie d'Urfe, QC, Canada) and imaged using the Kodak Image Station 2000R. After imaging, membranes probed with phospho-specific antibodies were stripped using Restore Plus Western blot stripping buffer (Thermo Fisher Scientific) and re-probed with primary antibodies specific to total protein as loading controls. Protein levels were normalized to either total protein or $G$ protein $\beta$ (G $\beta)$ values where appropriate. $G \beta$ antibody was purchased from Santa Cruz Biotechnology. The anti-Akt, phospho-specific-Akt (Ser473), ERK1/2 (p44/p42), phospho-specific-ERK1/2 (Thr202/Tyr204), IR $\beta$, antiFOXO1, and phospho-specific-FOXO1 (Ser256) antibodies were obtained from Cell Signaling Technology, Inc.

Published by Bioscientifica Ltd. 
A

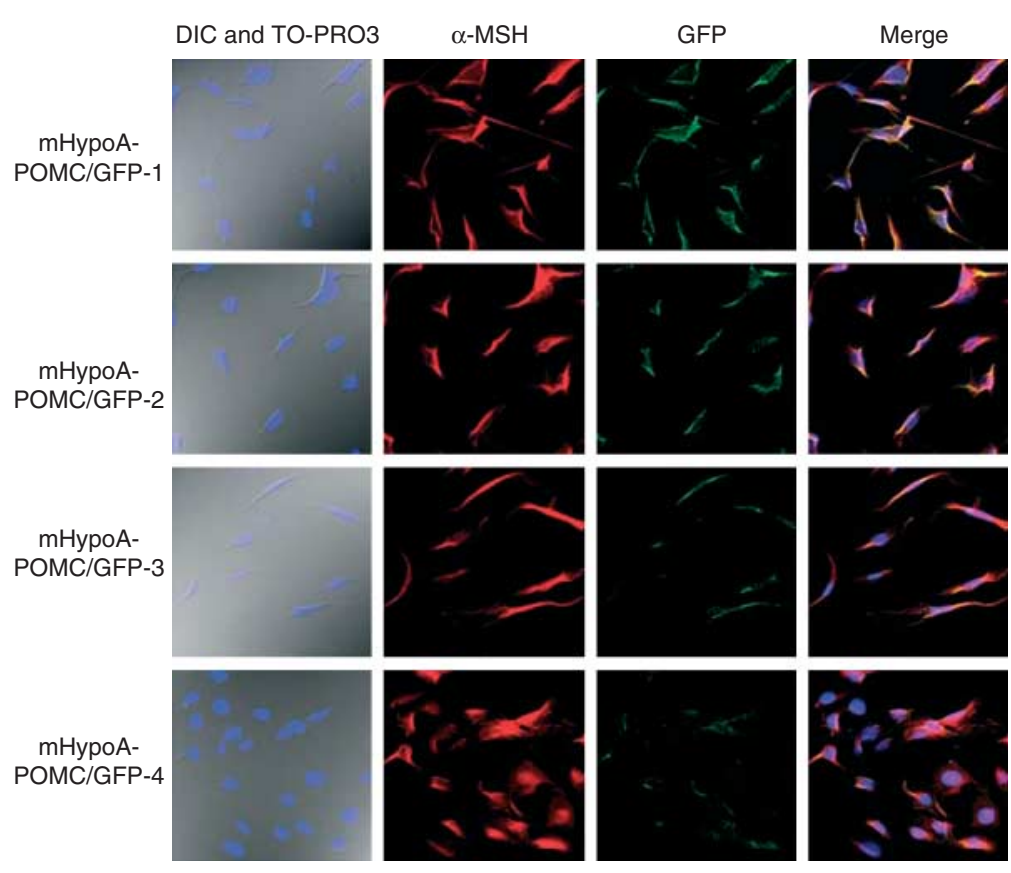

B

\begin{tabular}{|c|c|c|c|c|}
\hline & $\begin{array}{l}\text { mHypoA- } \\
\text { POMC/ } \\
\text { GFP-1 }\end{array}$ & $\begin{array}{l}\text { mHypoA- } \\
\text { POMC/ } \\
\text { GFP-2 }\end{array}$ & \begin{tabular}{|c|} 
mHypoA \\
POMC/ \\
GFP-3
\end{tabular} & $\begin{array}{l}\text { mHypoA } \\
\text { POMC/ } \\
\text { GFP-4 }\end{array}$ \\
\hline \multicolumn{5}{|l|}{$\begin{array}{l}\text { Peptide } \\
\text { mRNA }\end{array}$} \\
\hline POMC & + & + & + & + \\
\hline CART & + & + & + & + \\
\hline $\begin{array}{l}\text { Ta antigen } \\
\text { NSE }\end{array}$ & $\begin{array}{l}+ \\
+\end{array}$ & $\begin{array}{l}+ \\
+\end{array}$ & $\begin{array}{l}+ \\
+\end{array}$ & $\begin{array}{l}+ \\
+\end{array}$ \\
\hline \multicolumn{5}{|l|}{$\begin{array}{l}\text { Processing } \\
\text { enzyme mRNA }\end{array}$} \\
\hline PACE4 & + & + & + & + \\
\hline $\begin{array}{l}\text { PC1 } 13 \\
\text { ProSAAS }\end{array}$ & \pm & $\begin{array}{l} \pm \\
-\end{array}$ & \pm & \pm \\
\hline PC2 & + & + & + & + \\
\hline $7 \mathrm{~b} 2$ & + & + & + & + \\
\hline CPE & + & + & + & \\
\hline PAM & + & + & + & + \\
\hline N-AT & + & + & + & + \\
\hline \multicolumn{5}{|l|}{ Receptor mRNA } \\
\hline CNTFR & + & + & + & + \\
\hline CRFR1 & + & + & + & + \\
\hline CRFR2 & + & + & + & + \\
\hline ER $\alpha$ & + & + & + & + \\
\hline ER $\beta$ & + & - & + & + \\
\hline GHSR & + & + & + & + \\
\hline $\begin{array}{l}\text { Glp1R } \\
\text { GcaB }\end{array}$ & $\bar{t}$ & $\bar{t}$ & + & $\bar{t}$ \\
\hline $\begin{array}{l}\mathrm{Gcg} \\
5 \text {-HT1BR }\end{array}$ & $\begin{array}{lll}+ \\
+\end{array}$ & $\begin{array}{l}+ \\
+\end{array}$ & $\stackrel{+}{+}$ & ${ }^{+}$ \\
\hline $5-\mathrm{HT} 2 \mathrm{CR}$ & - & - & + & - \\
\hline & + & + & + & + \\
\hline MС3R & - & - & - & - \\
\hline MC4R & - & - & + & + \\
\hline ObRb & + & + & + & + \\
\hline \multicolumn{5}{|l|}{$\begin{array}{l}\text { Inflammatory } \\
\text { marker mRNA }\end{array}$} \\
\hline IL1 $1 \beta$ & - & + & + & + \\
\hline & 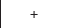 & + & + & + \\
\hline TNF $\alpha$ & - & + & + & + \\
\hline TLR4 & + & + & + & + \\
\hline TNF $\alpha R$ & + & + & + & + \\
\hline & + & + & + & + \\
\hline IL1BR & + & + & + & + \\
\hline $\begin{array}{l}\text { lkBo } \\
\text { CHOP }\end{array}$ & $\begin{array}{lll}+ \\
+\end{array}$ & $\begin{array}{l}+ \\
+\end{array}$ & $\begin{array}{l}+ \\
+\end{array}$ & $\begin{array}{l}+ \\
+\end{array}$ \\
\hline
\end{tabular}

\section{Figure 1}

(A) The mHypoA-POMC/GFP cell lines co-express $\alpha$-MSH and GFP. ICC was performed on each cell line with antibodies specific to $\alpha$-MSH (red) and GFP (green). The nucleic acid stain TO-PRO-3 was used to visualize cell nuclei (blue). (B) Screening of the mHypoA-POMC/GFP-1-4 cell lines. DNAse-treated RNA samples collected from mHypoA-POMC/GFP cells

\section{Statistical analysis}

Data were analyzed using SigmaPlot 12 software (SigmaPlot, San Jose, CA, USA) and are presented as mean \pm s.e.m. According to the nature of the data, one- or two-way ANOVA was used, followed by Bonferroni's post-hoc test, where a $P$ value of $<0.05$ was considered significant.

\section{Results}

\section{Characterization of mHypoA-POMC/GFP cell lines}

mHypoA-POMC/GFP cell lines were generated via immortalization and FAC sorting of primary hypothalamic cultures from four POMC-eGFP transgenic mice. Each cell line was probed using antibodies specific to $\alpha$-MSH and GFP and visualized using ICC to confirm cell phenotype (Fig. 1). ICC verified co-expression of $\alpha$-MSH and GFP in mHypoA-POMC/GFP cells in culture. One-step RT-PCR was performed to determine the gene expression profile of each cell line (Fig. 1), and all cell lines were found were used for RT-PCR. + indicates a strong band visible on the agarose gel whereas - indicates no visible amplification. All positive bands were excised from the gel, purified, and sent for sequencing to ensure correct identity of the product.

to express the neuronal marker, neuron-specific enolase (NSE), as well as the anorexigenic neuropeptides, POMC, and cocaine- and amphetamine-regulated transcript (CART). Transcript levels of IR and POMC posttranslational processing enzymes were also detected. Although all four mHypoA-POMC/GFP cell lines exhibit a general neuronal appearance including a cell body and axonal/ dendritic projections, they differ from each other in morphology and gene expression profile. We selected the mHypoA-POMC/GFP-1 cell line for further investigation due to higher expression levels of POMC and GFP than the other three cell lines, as shown by ICC (Fig. 1), as well as co-expression of the insulin signaling machinery.

\section{CNTF, insulin, and $\mathrm{KCl}$ directly increase $\alpha-\mathrm{MSH}$ secretion in the mHypoA-POMC/GFP-1 neurons}

In order to further validate the mHypoA-POMC/GFP 1 cell line as a representative model of POMC neurons, we analyzed $\alpha$-MSH secretion in response to $10 \mathrm{ng} / \mathrm{ml} \mathrm{CNTF}$, $10 \mathrm{nM}$ insulin, and $60 \mathrm{mM} \mathrm{KCl}$ as a positive control for

Published by Bioscientifica Ltd. 


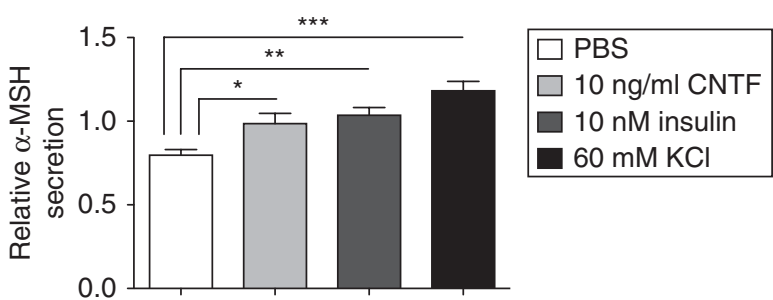

Figure 2

CNTF and insulin induce $\alpha$-MSH secretion in mHypoA-POMC/GFP-1 neurons. Cells were incubated in $5.5 \mathrm{mM}$ glucose media for $16 \mathrm{~h}$ prior to washing with $1 \times$ PBS. Cells were then treated with media containing PBS control or $60 \mathrm{mM} \mathrm{KCl}$ for $20 \mathrm{~min}$. $\alpha$-MSH-like immunoreactivity was assayed by collecting from cell culture media in triplicates for each sample. $\alpha$-MSH content was normalized over total protein content. Data shown are means \pm s.E.M. $(* * * P<0.001$ by one-way ANOVA, $n=7$ independent experiments). ${ }^{*} P<0.05 ; * * P<0.01 ; * * * P<0.001$.

maximal secretion. We demonstrate that CNTF, insulin, and $\mathrm{KCl}$ significantly increase $\alpha$-MSH secretion in the mHypoA-POMC/GFP-1 neurons (Fig. 2).

\section{CNTF and insulin induce Pomc mRNA expression in mHypoA-POMC/GFP-1 neurons}

To test the mHypoA-POMC/GFP-1 cell model for viability for gene regulation studies, we treated the cells with $10 \mathrm{ng} / \mathrm{ml} \mathrm{CNTF}$ or $10 \mathrm{nM}$ insulin and assessed mRNA expression levels of c-fos (Fos), a marker of neuronal activation (Sagar et al. 1988), and Pomc. Both CNTF and insulin treatments increased c-fos expression (Fig. 3A and B). Pomc mRNA levels were also increased at 1 and $2 \mathrm{~h}$ after administration of CNTF (Fig. 3C). At $4 \mathrm{~h}$ following treatment, insulin significantly increased Pomc transcript levels (Fig. 3D) and slightly decreased Insr (Ir) mRNA expression (Fig. 3E). There were no significant differences in gene expression of IRS1, IRS2, carboxypeptidase E (CPE), peptidyl $\alpha$-amidating monooxygenase (PAM), or $\mathrm{N}$-acetyltransferase $(\mathrm{N}$-AT) mRNA between treatment groups (Supplementary Figure 1, see section on supplementary data given at the end of this article). These results confirm that insulin directly regulates transcriptional activity of specific genes within POMC neurons.

\section{Insulin induces Akt and ERK phosphorylation in mHypoA-POMC/GFP-1 neurons}

Similar to insulin action in the periphery, insulin signal transduction in the CNS is mediated mainly through the PI3K and MAPK/ERK pathways (Vogt \& Bruning 2013). Insulin is known to act primarily through the PI3K-Akt pathway within POMC neurons while the function of the
MAPK pathway is less clear (Vogt \& Bruning 2013). In order to determine whether these key pathways are activated by insulin within the mHypoA-POMC/GFP-1 neurons, cells were treated with $10 \mathrm{nM}$ of insulin or PBS control over a 1-h time course. Compared with timematched controls, insulin caused robust phosphorylation of Akt at 5, 15, 30, and $60 \mathrm{~min}$ (Fig. 4A) and raised phospho-ERK1/2 levels at 5 and 15 min (Fig. 4B) following treatment, indicating activation of both the PI3K and MAPK pathways.

\section{Insulin signal transduction is disrupted by chronic insulin exposure}

To determine the cellular ramifications of POMC neuronal insulin resistance, we aimed to induce insulin resistance in mHypoA-POMC/GFP neurons and observe the
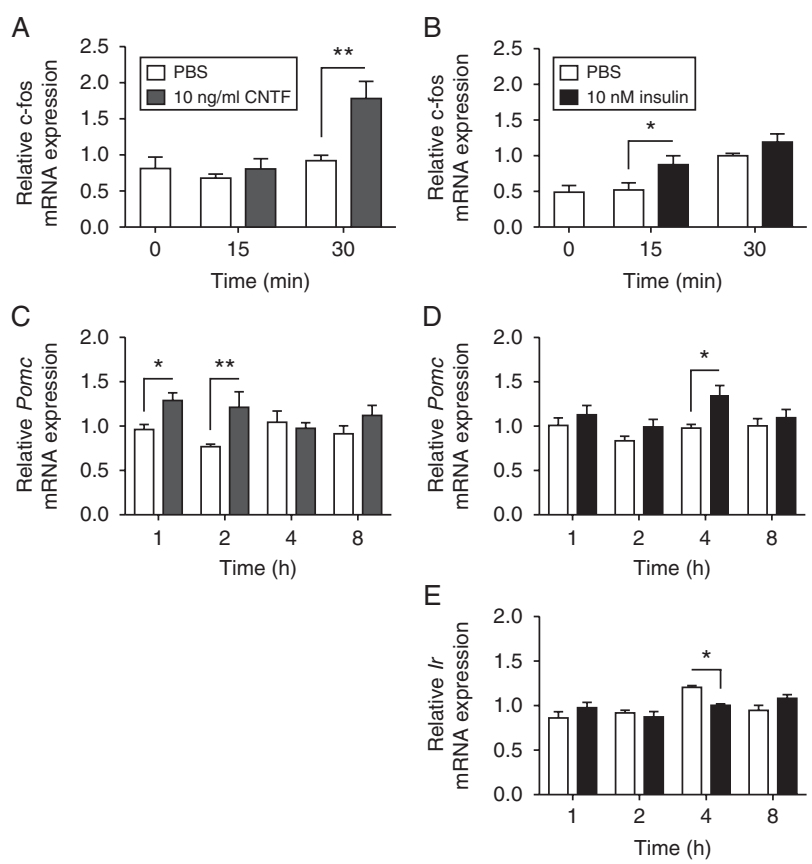

Figure 3

Gene expression levels in the mHypoA-POMC/GFP-1 neurons can be regulated by treatment with CNTF or insulin. Cells were treated with $10 \mathrm{ng} / \mathrm{ml}$ CNTF, $10 \mathrm{nM}$ insulin, or PBS vehicle, and RNA was isolated and treated with DNase prior to generating CDNA for qRT-PCR. Results are normalized to the levels of histone $3 A$ transcript and expressed as means \pm S.E.M. CNTF (A) and insulin (B) increased c-fos mRNA expression at 30 $(* * P<0.01$ by two-way ANOVA, $n=4$ independent experiments) and $15 \min \left({ }^{*} P<0.05, n=3\right.$ independent experiments) after treatment respectively. (C) CNTF also raised Pomc mRNA levels at $1(* P<0.05)$ and $2 \mathrm{~h}$ $(* * P<0.01)$ after treatment $(n=4$ independent experiments). At $4 \mathrm{~h}$ after treatment, insulin significantly upregulated Pomc (D) and reduced $\operatorname{Ir}(\mathrm{E})$ gene expression compared with time-matched controls $\left({ }^{*} P<0.05, n=4\right.$ independent experiments). 

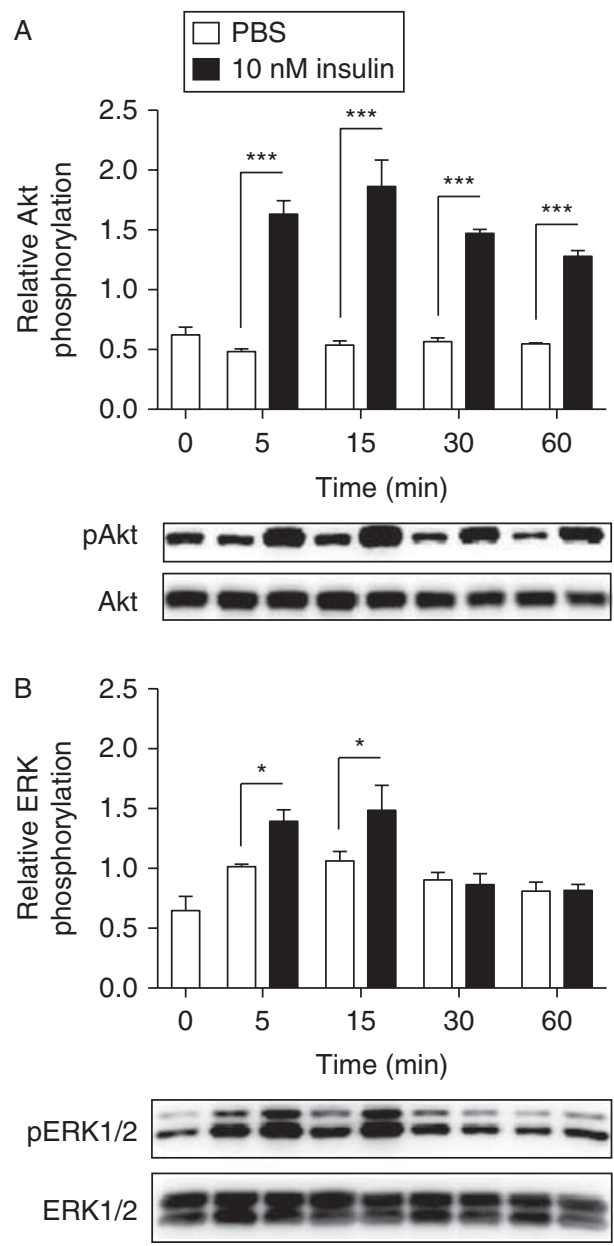

Figure 4

Insulin increases phosphorylation of second-messenger proteins in mHypoA-POMC/GFP-1 neurons. Cells were harvested over a 1-h time course after treatment with $10 \mathrm{nM}$ insulin or PBS. Protein was isolated and subjected to western blot analysis. Results depict levels of phospho-protein normalized to levels of total (phosphorylated and non-phosphorylated) protein (means \pm s.E.M.). Representative blots of phosphorylated and total protein are shown below each graph. Insulin caused activation of AKT (A) at all time points after treatment $(* * * P<0.001$ by two-way ANOVA, $n=3$ independent experiments) and ERK (B) at 5 and $15 \mathrm{~min}$ after treatment compared with time-matched controls $\left({ }^{*} P<0.05, n=5\right.$ independent experiments).

phosphorylation status of key signaling molecules. Our laboratory has optimized the procedure for the induction of insulin resistance in neuronal cell lines (Mayer \& Belsham 2010, Nazarians-Armavil et al. 2013). We have previously established that exposure to a minimum of $100 \mathrm{nM}$ of insulin for $24 \mathrm{~h}$ is required to induce a state of insulin resistance in our cell models. Thus, the mHypoAPOMC/GFP cell lines were pretreated with $100 \mathrm{nM}$ insulin or PBS vehicle for $24 \mathrm{~h}$ and then re-challenged with $10 \mathrm{nM}$ insulin or PBS control for $15 \mathrm{~min}$ prior to protein harvesting. It was determined that prolonged insulin exposure significantly attenuates insulin signal transduction, as demonstrated by the loss of insulin-induced phosphorylation of Akt and FOXO1 (Fig. 5 and Supplementary Figure 2, see section on supplementary data given at the end of this article). Furthermore, a substantial attenuation in protein levels of the $\beta$ subunit of the IR (IR $\beta$ ) (Fig. 5 and Supplementary Figure 2) was observed in all four mHypoA-POMC/GFP cell lines following insulin pretreatment.

\section{Pretreatment with insulin inhibits insulin-mediated regulation of gene expression}

In order to determine the effects of insulin resistance on insulin modulation of POMC neuronal function, the insulin-mediated regulation of gene transcript levels was analyzed following the induction of insulin resistance. mHypoA-POMC/GFP-1 cells were subjected to prolonged insulin exposure as described earlier and then re-challenged with $10 \mathrm{nM}$ insulin or PBS vehicle. RNA was isolated $4 \mathrm{~h}$ following treatment and transcript levels were analyzed using qRT-PCR. In cells pretreated with vehicle, insulin re-challenge increased Pomc mRNA levels (Fig. 6A) and decreased Ir gene expression (Fig. 6B). These changes were eliminated in cells subjected to insulin pretreatment (Fig. 6A and B). Insulin (100 nM) pretreatment also caused an induction in Pomc mRNA expression independent of re-challenge with $10 \mathrm{nM}$ insulin (Fig. 6A).

\section{Discussion}

In this report, we have characterized our newly generated cell models, mHypoA-POMC/GFP lines 1-4, representing the mixed population of in vivo POMC neurons. All cell lines display neuronal morphology and express NSE, a marker of mature, fully differentiated neurons. ICC revealed co-expression of GFP and $\alpha$-MSH, indicating successful FAC sorting. The co-expression of POMC with CART is consistent with findings obtained through immunohistochemistry on hypothalamic slices (Elias et al. 1998). Additionally, the presence of transcripts encoding IR and POMC posttranslational processing enzymes suggests that the cells are suitable for investigating hormonal regulation of POMC and its derivatives, such as $\alpha$-MSH. Given the results of our initial investigation, we proceeded to test mHypoA-POMC/GFP-1 cells for the ability to secrete $\alpha$-MSH. Our EIA data confirm that the mHypoA-POMC/GFP-1 cell line not only has the capability to synthesize Pomc mRNA but also to secrete the

Published by Bioscientifica Ltd. 

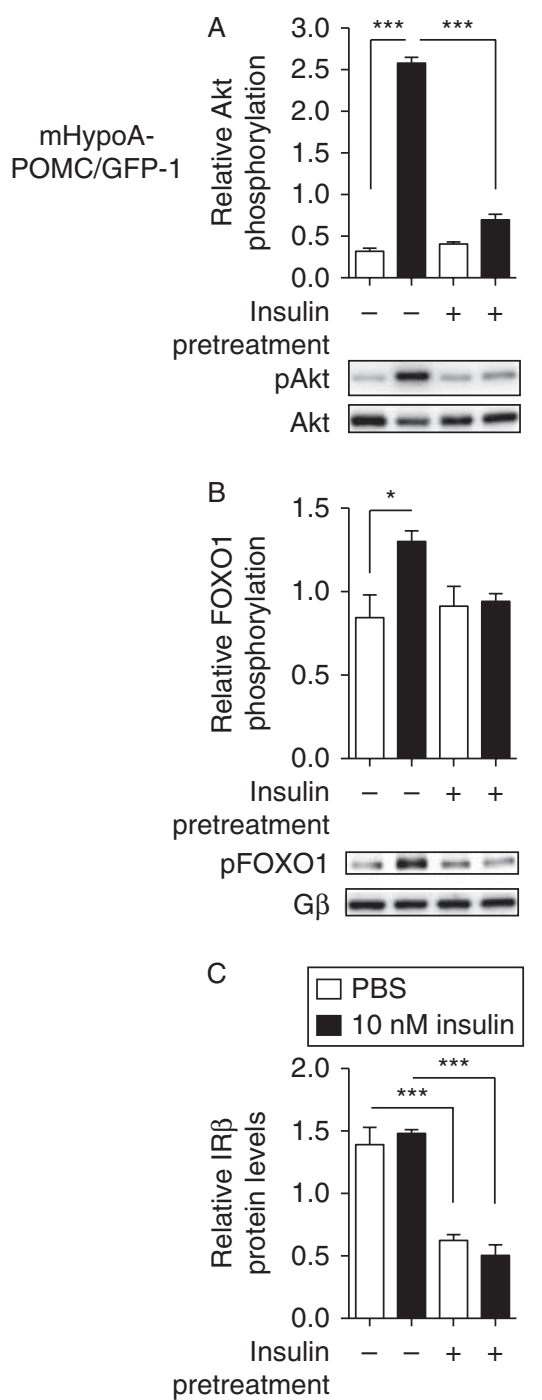

IR $=-\infty$

$\mathrm{G} \beta$

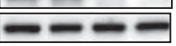

Figure 5

Insulin pretreatment attenuates insulin signal transduction in $\mathrm{mHypoA}-$ POMC/GFP-1 neurons. Cells were pretreated with either $100 \mathrm{nM}$ insulin (+) or PBS (-) for $24 \mathrm{~h}$, washed with PBS for $1 \mathrm{~h}$, and then re-challenged with $10 \mathrm{nM}$ insulin or PBS for $15 \mathrm{~min}$. Results are normalized to levels of total protein or G $\beta$ (means \pm s.E.M., $n=3-4$ independent experiments). Representative blots are shown below each graph. Insulin pretreatment severely attenuates insulin-induced phosphorylation of AKT ( $* * * P<0.001$ by oneway ANOVA) and of FOXO1 in mHypoA-POMC/GFP-1 ( $P<0.05)$. Total IR $\beta$ levels are also reduced by insulin pretreatment in mHypoA-POMC/GFP-1 $(* * * P<0.001)$.

$\alpha$-MSH peptide in response to CNTF and insulin. While insulin has been shown through electrophysiological studies to cause an acute hyperpolarization of POMC neurons (Choudhury et al. 2005, Plum et al. 2006b), the increase observed in $\alpha$-MSH release from the mHypoAPOMC/GFP-1 line after $1 \mathrm{~h}$ of treatment is more consistent with the role of insulin, similar to CNTF in decreasing feeding and body weight in the whole animal (Air et al. 2002, Kokoeva et al. 2005, Brown et al. 2006, Purser et al. 2013). The disparity between electrophysiological data, and results from our cell line and from in vivo work, should be explored further to improve our understanding of insulin action in POMC neurons. Our cell model may be useful in bridging this gap, as studies on the regulation of $\alpha$-MSH secretion specifically from hypothalamic POMC neurons are not possible to perform in vivo or ex vivo.

We have also demonstrated that gene expression in the mHypoA-POMC/GFP-1 neurons is modulated in response to anorexigenic hormones CNTF and insulin. The cells were treated with CNTF as a positive control for induction of c-fos mRNA, a marker of neuronal activation (Sagar et al. 1988), and Pomc mRNA (Ambati et al. 2007), as the use of CNTF to stimulate neuronal proliferation during the immortalization process selects for neurons responsive
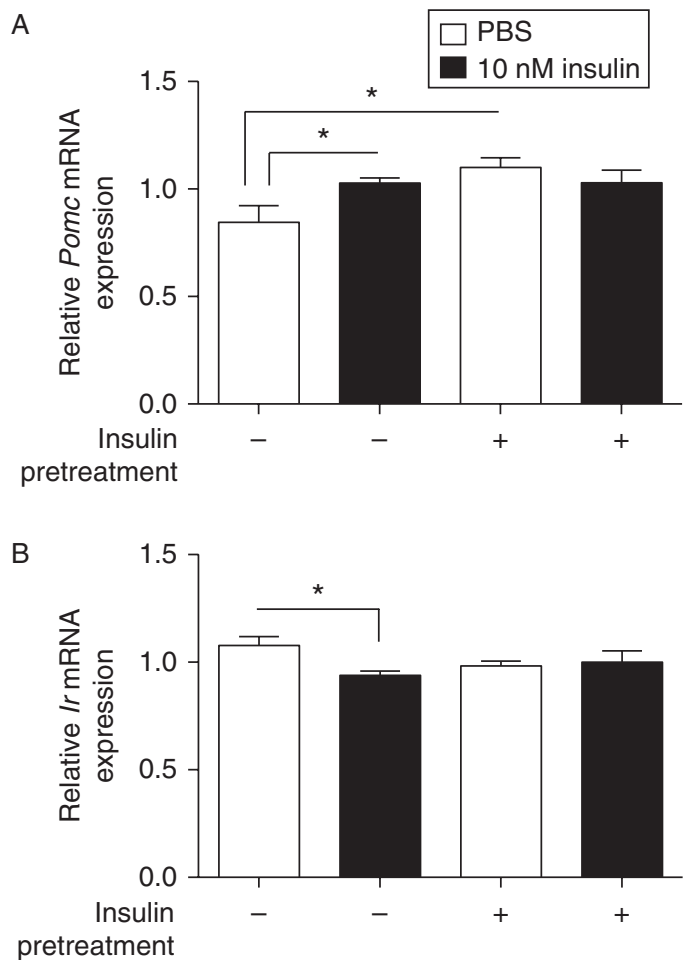

\section{Figure 6}

Pretreatment of mHypoA-POMC/GFP-1 neurons with $100 \mathrm{nM}$ insulin dysregulates insulin-induced changes in gene expression. Cells were pretreated for $24 \mathrm{~h}$ with $100 \mathrm{nM}$ insulin (+) or PBS (-), followed by re-challenge with $10 \mathrm{nM}$ insulin or PBS for $4 \mathrm{~h}$. Results are normalized to histone 3A mRNA expression levels and expressed as means \pm s.E.M. Insulin re-challenge increased POMC transcript levels $(A, * P<0.05$ by one-way ANOVA, $n=5$ independent experiments) and suppressed IR transcript levels ( $B, * P<0.05, n=6$ independent experiments) in cells pretreated with vehicle, but not in cells pretreated with insulin. 
to CNTF. Having established that CNTF regulates gene expression in our cell model, we then treated the neurons with insulin and found that it also increased levels of c-fos and POMC. These results provide evidence that the mHypoA-POMC/GFP-1 neurons respond appropriately to insulin, as several groups have shown that insulin regulates transcriptional events within POMC neurons in vivo to induce expression of the Pomc gene (Brown et al. 2006, Kitamura et al. 2006, Plum et al. 2006a). Further studies will determine whether this effect is due to transcriptional regulation at the level of the promoter or to changes in RNA stability. Interestingly, while POMC expression was stimulated in the mHypoA-POMC/GFP-1 cells at $4 \mathrm{~h}$ after treatment, Ir mRNA levels were slightly decreased. As IR expression rebounded by $8 \mathrm{~h}$ despite the ongoing presence of insulin in the media, the transient decrease at $4 \mathrm{~h}$ likely does not represent a control mechanism for continued exposure to insulin. This phenomenon may be worth exploring further, as the acute effects of insulin on IR gene expression have not been previously studied.

POMC is a precursor polypeptide that undergoes several posttranslational cleavage steps to generate a number of bioactive peptides. This process is regulated by the tissue-specific expression of prohormone convertases and processing enzymes (Pritchard et al. 2002, Mountjoy 2010). Within the hypothalamus, of particular interest to metabolic regulation is the potent anorexigenic neuropeptide, $\alpha$-MSH. POMC neurons modulate energy homeostasis principally through this cleavage product. In order to generate $\alpha$-MSH, POMC is initially cleaved by proprotein convertase $1 / 3(\mathrm{PC} 1 / 3)$ into pro-ACTH and $\beta$-lipotrophin ( $\beta$-LPH). Pro-ACTH is again cleaved by $\mathrm{PC} 1 / 3$, generating ACTH. Further processing requires PC2, which is expressed in the hypothalamus but not the pituitary. PC2 cleaves ACTH into ACTH1-17 and corticotrophin-like intermediate lobe peptide. PC2 function is modulated by $7 \mathrm{~b} 2$, which can have differential effects on POMC processing by acting either as an inhibitor or a chaperone of PC2 (Lindberg et al. 1995). Next, CPE removes C-terminal basic residues from ACTH1-17 and PAM amidates the resulting product, forming desacetyl $\alpha$-MSH (DA- $\alpha$ MSH). $N$-AT converts DA- $\alpha$ MSH into mature $\alpha$-MSH. It has been speculated that POMC posttranslational processing may be influenced by energy status and metabolic disease (Pritchard et al. 2002). As little is known regarding the regulation of POMC posttranslational processing by insulin, we conducted mRNA studies on Cpe, Pam, and N-at2. It was found that in the mHypoAPOMC/GFP-1 neurons, insulin treatment did not affect transcript levels of Cpe, Pam, and $\mathrm{N}$-at2 at the time points assessed. Whether or not insulin regulates the protein expression or activity levels of these enzymes may be an interesting topic for future investigation.

The two key signal transduction cascades that mediate insulin action in both the periphery and the CNS are the PI3K-Akt and MAPK/ERK pathways (Vogt \& Bruning 2013). We have confirmed that signaling in both pathways is intact in our POMC-expressing cell models as seen by the phosphorylation of Akt and ERK1/2 in response to insulin (data not shown for mHypoA-POMC/GFP lines $2-4)$. Hence, we proceeded to perform studies on insulin resistance in the mHypoA-POMC/GFP cell lines. The latest research has suggested that hyperinsulinemia leading to insulin resistance may be the primary cause of leptin resistance and obesity in vivo (Corkey 2012, Mehran et al. 2013). How cellular insulin resistance can hinder hormonal modulation of POMC neurons in particular is a pressing question that remains to be answered. Similar to previous studies from our laboratory on other hypothalamic cell lines, we found that pretreatment of the mHypoA-POMC/GFP neurons with elevated levels of insulin led to cellular insulin resistance as determined by the inability of insulin to induce Akt phosphorylation (Mayer \& Belsham 2010, Nazarians-Armavil et al. 2013). However, the changes in gene expression that may accompany hormone resistance in POMC neurons have not yet been addressed and this may be a fundamental aspect of central insulin resistance. Insulin pretreatment in mHypoA-POMC/GFP-1 cells abolished the increase in POMC and decrease in Ir gene expression observed after insulin treatment in non-resistant cells. The dysregulation of POMC expression is particularly significant, as mice exhibiting lower Pomc gene expression due to disturbances in the PI3K pathway become obese and hyperphagic (Belgardt et al. 2008, Iskandar et al. 2010). Additionally, after the induction of insulin resistance, the mHypoAPOMC/GFP cell lines showed reduced phosphorylation of second-messenger proteins in the insulin signal transduction pathway, such as Akt and FOXO1. The failure of Akt to phosphorylate FOXO1 is a possible cause of the dysregulation of Pomc expression. The PI3K-FOXO1 pathway is essential to POMC neuronal function as disturbance or inhibition of key components of the PI3K pathway lead to an increased body weight associated with hyperphagia (Niswender et al. 2003, Belgardt et al. 2008, Iskandar et al. 2010). Furthermore, all four mHypoAPOMC/GFP cell lines exhibited repressed IR protein levels after prolonged exposure to insulin, contributing to the onset of the insulin-resistant phenotype. Collectively, our

Published by Bioscientifica Ltd. 
data suggest that high levels of insulin can directly disrupt POMC neuronal function at the cellular level, resulting in dysregulation of the POMC transcript, which could further exacerbate the metabolic syndrome.

It has been established that hypothalamic POMC neurons play critical roles in the maintenance of energy and glucose homeostasis. However, the cellular mechanisms through which this regulation is achieved could be elucidated in far more detail if representative cell models were available for performing promoter studies, for treatment with pharmacological inhibitors of common signal transduction cascades, and for assessing secretion profiles from specific neuronal subpopulations. To this end, the mHypoA-POMC/GFP-1-4 neuronal cell models serve as an invaluable tool for gaining mechanistic insight into the central melanocortin system in healthy and diseased states. Future directions include the detailed molecular investigation of other processes that may be involved in the metabolic syndrome, such as hypothalamic autophagy (Kaushik et al. 2012), glucose sensing (Parton et al. 2007), neuroinflammation (Thaler et al. 2012), and the circadian regulation of metabolism (Jamali \& Tramu 1997). It would also be of interest to further characterize each of the four cell lines, as based on their distinct morphologies and gene expression profiles, they may contain different subpopulations of POMC neurons. The presence of subtypes of POMC neurons in vivo is beginning to garner recognition in the literature, with recent evidence showing that insulin vs leptin responsiveness, and glutamate vs GABA production, occur in discrete POMC neuronal subpopulations with distinct morphologies and distributions within the ARC (Williams et al. 2010, Wittmann et al. 2013). To date, we have found that the four lines are similar, but do display some distinct differences in expression profiles and neuronal morphology. We have also begun to analyze the inflammatory response in each of the four cell models to determine whether each responds equally to tumor necrosis factor $\alpha(\mathrm{TNF} \alpha)$, a pro-inflammatory cytokine known to be increased in obesity and postulated to be induced by high-fat diet. TNF $\alpha$ is also a downstream component of the canonical inflammatory cascade, inhibitor of $\mathrm{I} \kappa \mathrm{B}$ kinase $\beta /$ nuclear factor $\kappa \mathrm{B}$ pathway, which is also active in the hypothalamus (Zhang et al. 2008). Interestingly, mHypoA-POMC/GFP-1 does not express $\mathrm{NF} \kappa \mathrm{B}$ but still responds to TNF $\alpha$, as do the other three cell lines. However, only in the mHypoAPOMC/GFP-2 line do we detect an increase in POMC expression upon exposure to TNF $\alpha$ (Welhauser $\&$ Belsham, manuscript in preparation). These studies are in progress to understand the downstream signaling events initiated by high-fat diet, palmitate, or TNF $\alpha$ exposure. Much remains to be elucidated regarding the physiological roles of subtypes of POMC neurons. The knowledge gained through the analysis of the mHypoA-POMC/GFP cell lines will complement in vivo studies, leading to a better understanding of POMC neuronal function in metabolic disorders such as obesity and T2DM and ultimately toward the development of novel therapeutic strategies to alter their course.

\section{Supplementary data}

This is linked to the online version of the paper at http://dx.doi.org/10.1530/ JOE-13-0334.

\section{Declaration of interest}

The authors declare that there is no conflict of interest that could be perceived as prejudicing the impartiality of the research reported.

\section{Funding}

We acknowledge funding from the Canadian Institutes for Health Research (CIHR Operating grant MOP-74712), Canada Foundation for Innovation, and Canada Research Chairs Program (to D D B). A N-A was supported by a CIHR MSc Studentship, C B L was supported by a Banting and Best Diabetes Centre (BBDC), Natural Sciences and Engineering Research Council, and Endocrine Society Summer Studentships, and W Y was supported by a BBDC Summer Studentship.

\section{Acknowledgements}

The authors would like to thank Dr Leigh Wellhauser for critical reading of the manuscript.

\section{References}

Air EL, Benoit SC, Clegg DJ, Seeley RJ \& Woods SC 2002 Insulin and leptin combine additively to reduce food intake and body weight in rats. Endocrinology 143 2449-2452. (doi:10.1210/en.143.6.2449)

Ambati S, Duan J, Duff E, Choi YH, Hartzell DL, Della-Fera MA \& Baile CA 2007 Gene expression in arcuate nucleus-median eminence of rats treated with leptin or ciliary neurotrophic factor. BioFactors $\mathbf{3 1}$ 133-144. (doi:10.1002/biof.5520310204)

Arora S \& Anubhuti 2006 Role of neuropeptides in appetite regulation and obesity - a review. Neuropeptides 40 375-401. (doi:10.1016/j.npep.2006. 07.001)

Baskin DG, Figlewicz Lattemann D, Seeley RJ, Woods SC, Porte D Jr \& Schwartz MW 1999 Insulin and leptin: dual adiposity signals to the brain for the regulation of food intake and body weight. Brain Research 848 114-123. (doi:10.1016/S0006-8993(99)01974-5)

Belgardt BF, Husch A, Rother E, Ernst MB, Wunderlich FT, Hampel B, Klockener T, Alessi D, Kloppenburg P \& Bruning JC 2008 PDK1 deficiency in POMC-expressing cells reveals FOXO1-dependent and -independent pathways in control of energy homeostasis and stress response. Cell Metabolism 7 291-301. (doi:10.1016/j.cmet.2008.01.006)

Published by Bioscientifica Ltd. 
Belsham DD, Cai F, Cui H, Smukler SR, Salapatek AM \& Shkreta L 2004 Generation of a phenotypic array of hypothalamic neuronal cell models to study complex neuroendocrine disorders. Endocrinology 145 393-400. (doi:10.1210/en.2003-0946)

Belsham DD, Fick LJ, Dalvi PS, Centeno ML, Chalmers JA, Lee PK, Wang Y, Drucker DJ \& Koletar MM 2009 Ciliary neurotrophic factor recruitment of glucagon-like peptide-1 mediates neurogenesis, allowing immortalization of adult murine hypothalamic neurons. FASEB Journal 23 4256-4265. (doi:10.1096/fj.09-133454)

Brown LM, Clegg DJ, Benoit SC \& Woods SC 2006 Intraventricular insulin and leptin reduce food intake and body weight in C57BL/6J mice. Physiology \& Behavior 89 687-691. (doi:10.1016/j.physbeh.2006.08. 008)

Chomczynski P \& Sacchi N 1987 Single-step method of RNA isolation by acid guanidinium thiocyanate-phenol-chloroform extraction. Analytical Biochemistry 162 156-159. (doi:10.1016/00032697(87)90021-2)

Choudhury AI, Heffron H, Smith MA, Al-Qassab H, Xu AW, Selman C, Simmgen M, Clements M, Claret M, Maccoll G et al. 2005 The role of insulin receptor substrate 2 in hypothalamic and $\beta$ cell function. Journal of Clinical Investigation 115 940-950. (doi:10.1172/ JCI200524445)

Cone RD, Cowley MA, Butler AA, Fan W, Marks DL \& Low MJ 2001 The arcuate nucleus as a conduit for diverse signals relevant to energy homeostasis. International Journal of Obesity and Related Metabolic Disorders 25(Suppl 5) S63-S67. (doi:10.1038/sj.ijo.0801913)

Corkey BE 2012 Banting lecture 2011: hyperinsulinemia: cause or consequence? Diabetes 61 4-13. (doi:10.2337/db11-1483)

Couvreur O, Aubourg A, Crepin D, Degrouard J, Gertler A, Taouis M \& Vacher CM 2011 The anorexigenic cytokine ciliary neurotrophic factor stimulates POMC gene expression via receptors localized in the nucleus of arcuate neurons. American Journal of Physiology. Endocrinology and Metabolism 302 E458-E467. (doi:10.1152/ajpendo.00388.2011)

Dhillon SS, McFadden SA, Chalmers JA, Centeno ML, Kim GL \& Belsham DD 2011 Cellular leptin resistance impairs the leptin-mediated suppression of neuropeptide Y secretion in hypothalamic neurons. Endocrinology 152 4138-4147. (doi:10.1210/en.2011-0178)

Elias CF, Lee C, Kelly J, Aschkenasi C, Ahima RS, Couceyro PR, Kuhar MJ, Saper CB \& Elmquist JK 1998 Leptin activates hypothalamic CART neurons projecting to the spinal cord. Neuron 21 1375-1385. (doi:10.1016/S0896-6273(00)80656-X)

HillJW, Elias CF, Fukuda M, Williams KW, Berglund ED, Holland WL, Cho YR, Chuang JC, Xu Y, Choi M et al. 2010 Direct insulin and leptin action on pro-opiomelanocortin neurons is required for normal glucose homeostasis and fertility. Cell Metabolism 11 286-297. (doi:10.1016/j.cmet.2010. 03.002)

Iskandar K, Cao Y, Hayashi Y, Nakata M, Takano E, Yada T, Zhang C, Ogawa W, Oki M, Chua S Jr et al. 2010 PDK-1/FoxO1 pathway in POMC neurons regulates Pomc expression and food intake. American Journal of Physiology. Endocrinology and Metabolism 298 E787-E798. (doi:10.1152/ajpendo. 00512.2009)

Jamali AK \& Tramu G 1997 Daily cycle of fos expression within hypothalamic POMC neurons of the male rat. Brain Research $\mathbf{7 7 1}$ 45-54. (doi:10.1016/S0006-8993(97)00767-1)

Kaushik S, Arias E, Kwon H, Lopez NM, Athonvarangkul D, Sahu S, Schwartz GJ, Pessin JE \& Singh R 2012 Loss of autophagy in hypothalamic POMC neurons impairs lipolysis. EMBO Reports 13 258-265. (doi:10.1038/embor.2011.260)

Kim MS, Pak YK, Jang PG, Namkoong C, Choi YS, Won JC, Kim KS, Kim SW, Kim HS, Park JY et al. 2006 Role of hypothalamic Foxo1 in the regulation of food intake and energy homeostasis. Nature Neuroscience $\mathbf{9}$ 901-906. (doi:10.1038/nn1731)

Kitamura T, Feng Y, Kitamura YI, Chua SC Jr, Xu AW, Barsh GS, Rossetti L \& Accili D 2006 Forkhead protein FoxO1 mediates Agrp-dependent effects of leptin on food intake. Nature Medicine 12 534-540. (doi:10.1038/ $\mathrm{nm} 1392)$
Kokoeva MV, Yin H \& Flier JS 2005 Neurogenesis in the hypothalamus of adult mice: potential role in energy balance. Science 310 679-683. (doi:10.1126/science.1115360)

Konner AC \& Bruning JC 2012 Selective insulin and leptin resistance in metabolic disorders. Cell Metabolism 16 144-152. (doi:10.1016/j.cmet. 2012.07.004)

Lindberg I, van den Hurk WH, Bui C \& Batie CJ 1995 Enzymatic characterization of immunopurified prohormone convertase 2: potent inhibition by a 7B2 peptide fragment. Biochemistry 34 5486-5493. (doi:10.1021/bi00016a020)

Mayer CM \& Belsham DD 2010 Central insulin signaling is attenuated by long-term insulin exposure via insulin receptor substrate-1 serine phosphorylation, proteasomal degradation, and lysosomal insulin receptor degradation. Endocrinology 151 75-84. (doi:10.1210/en.20090838)

Mehran AE, Templeman NM, Brigidi GS, Lim GE, Chu KY, Hu X, Botezelli JD, Asadi A, Hoffman BG, Kieffer TJ et al. 2013 Hyperinsulinemia drives dietinduced obesity independently of brain insulin production. Cell Metabolism 16 723-737. (doi:10.1016/j.cmet.2012.10.019)

Morton GJ, Cummings DE, Baskin DG, Barsh GS \& Schwartz MW 2006 Central nervous system control of food intake and body weight. Nature 443 289-295. (doi:10.1038/nature05026)

Mountjoy KG 2010 Functions for pro-opiomelanocortin-derived peptides in obesity and diabetes. Biochemical Journal 428 305-324. (doi:10.1042/ BJ20091957)

Mountjoy KG \& Wong J 1997 Obesity, diabetes and functions for proopiomelanocortin-derived peptides. Molecular and Cellular Endocrinology 128 171-177. (doi:10.1016/S0303-7207(96)04017-8)

Nazarians-Armavil A, Menchella JA \& Belsham DD 2013 Cellular insulin resistance disrupts leptin-mediated control of neuronal signaling and transcription. Molecular Endocrinology 27 990-1003. (doi:10.1210/me. 2012-1338)

Niswender KD, Morrison CD, Clegg DJ, Olson R, Baskin DG, Myers MG Jr, Seeley RJ \& Schwartz MW 2003 Insulin activation of phosphatidylinositol 3-kinase in the hypothalamic arcuate nucleus: a key mediator of insulin-induced anorexia. Diabetes 52 227-231. (doi:10.2337/ diabetes.52.2.227)

Padilla SL, Reef D \& Zeltser LM 2012 Defining POMC neurons using transgenic reagents: impact of transient Pomc expression in diverse immature neuronal populations. Endocrinology 153 1219-1231. (doi:10.1210/en.2011-1665)

Parton LE, Ye CP, Coppari R, Enriori PJ, Choi B, Zhang CY, Xu C, Vianna CR, Balthasar N, Lee CE et al. 2007 Glucose sensing by POMC neurons regulates glucose homeostasis and is impaired in obesity. Nature $\mathbf{4 4 9}$ 228-232. (doi:10.1038/nature06098)

Plum L, Belgardt BF \& Bruning JC 2006a Central insulin action in energy and glucose homeostasis. Journal of Clinical Investigation 116 1761-1766. (doi:10.1172/JCI29063)

Plum L, Ma X, Hampel B, Balthasar N, Coppari R, Munzberg H, Shanabrough M, Burdakov D, Rother E, Janoschek R et al. $2006 \mathrm{~b}$ Enhanced PIP3 signaling in POMC neurons causes KATP channel activation and leads to diet-sensitive obesity. Journal of Clinical Investigation 116 1886-1901. (doi:10.1172/JCI27123)

Pritchard LE, Turnbull AV \& White A 2002 Pro-opiomelanocortin processing in the hypothalamus: impact on melanocortin signalling and obesity. Journal of Endocrinology 172 411-421. (doi:10.1677/joe.0. 1720411)

Purser MJ, Dalvi PS, Wang ZC \& Belsham DD 2013 The cytokine ciliary neurotrophic factor (CNTF) activates hypothalamic urocortinexpressing neurons both in vitro and in vivo. PLoS ONE 8 e61616. (doi:10.1371/journal.pone.0061616)

Reusch JE, Bhuripanyo P, Carel K, Leitner JW, Hsieh P, DePaolo D \& Draznin B 1995 Differential requirement for p21ras activation in the metabolic signaling by insulin. Journal of Biological Chemistry 270 2036-2040. (doi:10.1074/jbc.270.5.2036) 
Sagar SM, Sharp FR \& Curran T 1988 Expression of c-fos protein in brain: metabolic mapping at the cellular level. Science 240 1328-1331. (doi:10.1126/science.3131879)

Thaler JP, Yi CX, Schur EA, Guyenet SJ, Hwang BH, Dietrich MO, Zhao X, Sarruf DA, Izgur V, Maravilla KR et al. 2012 Obesity is associated with hypothalamic injury in rodents and humans. Journal of Clinical Investigation 122 153-162. (doi:10.1172/JCI59660)

Varela L \& Horvath TL 2012 Leptin and insulin pathways in POMC and AgRP neurons that modulate energy balance and glucose homeostasis. EMBO Reports 13 1079-1086. (doi:10.1038/embor.2012.174)

Vogt MC \& Bruning JC 2013 CNS insulin signaling in the control of energy homeostasis and glucose metabolism - from embryo to old age. Trends in Endocrinology and Metabolism 24 76-84. (doi:10.1016/j.tem. 2012.11.004)

Williams KW, Margatho LO, Lee CE, Choi M, Lee S, Scott MM, Elias CF \& Elmquist JK 2010 Segregation of acute leptin and insulin effects in distinct populations of arcuate proopiomelanocortin neurons.
Journal of Neuroscience 30 2472-2479. (doi:10.1523/JNEUROSCI.311809.2010)

Wittmann G, Hrabovszky E \& Lechan RM 2013 Distinct glutamatergic and GABAergic subsets of hypothalamic proopiomelanocortin neurons revealed by in situ hybridization in male rats and mice. Journal of Comparative Neurology 521 3287-3302. (doi:10.1002/cne.23350)

$\mathrm{Xu}$ Y, Jones JE, Kohno D, Williams KW, Lee CE, Choi MJ, Anderson JG, Heisler LK, Zigman JM, Lowell BB et al. 2008 5-HT2CRs expressed by pro-opiomelanocortin neurons regulate energy homeostasis. Neuron $\mathbf{6 0}$ 582-589. (doi:10.1016/j.neuron.2008.09.033)

Xu Y, Berglund ED, Sohn JW, Holland WL, Chuang JC, Fukuda M, Rossi J, Williams KW, Jones JE, Zigman JM et al. 2010 5-HT2CRs expressed by pro-opiomelanocortin neurons regulate insulin sensitivity in liver. Nature Neuroscience 13 1457-1459. (doi:10.1038/nn.2664)

Zhang X, Zhang G, Zhang H, Karin M, Bai H \& Cai D 2008 Hypothalamic IKK $\beta / \mathrm{NF}-\mathrm{KB}$ and ER stress link overnutrition to energy imbalance and obesity. Cell 135 61-73. (doi:10.1016/j.cell.2008.07.043)

Received in final form 1 October 2013

Accepted 17 October 2013

Accepted Preprint published online 17 October 2013
(C) 2014 Society for Endocrinology Printed in Great Britain
Published by Bioscientifica Ltd. 